\title{
Backlash against the Court of Justice of the EU? The Recent Jurisprudence of the German Constitutional Court on EU Fundamental Rights as a Standard of Review
}

\author{
Dana Burchardt*
}

(Received 23 February 2020; accepted 24 February 2020)

\begin{abstract}
This article discusses two landmark judgements by the German Federal Constitutional Court (CC) on the relationship between domestic and EU fundamental rights protection (Right to be forgotten I and II). In these judgements, for the first time, the CC uses EU fundamental rights as a standard of review. In addition, the CC establishes a novel framework of "parallel applicability" of EU and domestic fundamental rights for subject matters that are not fully harmonized by EU law. The article first presents the new approach, showing that it structurally changes the parameters of the relationship between the CC and the CJEU. Second, the article assesses the legal-political tendency reflected in this change: is this constructive dialogue or rather pushback against the CJEU? The article argues that this new jurisprudence should be characterized as an instance of resistance. The CC resists against the CJEU in its function as fundamental rights court, attempting to reduce the authority of the CJEU and reversing a development that it considered to be unfavourable to its own authority. This is structural pushback aimed at the CJEU's function rather than at individual decisions or norms - however, without rejection the CJEU as an institution altogether.
\end{abstract}

Keywords: EU fundamental rights protection; German Federal Constitutional Court; Right to be forgotten I and II; EU Fundamental Rights Charter as a standard of review; pushback against the CJEU

\section{A. Introduction}

In two landmark judgements delivered on Nov. 6, 2019 (1 BvR 276/17 and 1 BvR 16/13), the German Federal Constitutional Court (CC) overturned its jurisprudence on the relationship between the domestic fundamental rights protection and the fundamental rights protection provided by EU law. Going beyond its previous approach to only assess domestic fundamental rights and whether they are respected, it now decided to also use EU fundamental rights as a standard of review in certain situations. In addition, the court establishes a novel framework of "parallel applicability" of EU and domestic fundamental rights.

The initial scholarly feedback to these decisions was rather positive. Several commentators welcomed the new approach emphasizing that it allows for the CC to be "back in the game", ${ }^{1}$ arguing that the approach would focus on what links EU and domestic law rather than on what divides it, ${ }^{2}$ or

\footnotetext{
${ }^{\star}$ Dr. iur., postdoctoral researcher at Humboldt University Berlin.

${ }^{1}$ Walther Michl, In Vielfalt geeinte Grundrechte, VeRFASSUNGSBLOG (Nov 27, 2019), https://verfassungsblog.de/in-vielfaltgeeinte-grundrechte/.

${ }^{2} I d$.
}

(C) The Author(s) 2020. Published by Cambridge University Press on behalf of the German Law Journal. This is an Open Access article, distributed under the terms of the Creative Commons Attribution-NonCommercial licence (http://creativecommons.org/licenses/by-nc/4.0/), which permits unrestricted re-use, distribution, and reproduction in any medium, provided the original work is properly cited. 
highlighting that the new approach strengthens the CC institutionally and that it gives the CC a "new strong voice" in the European system of fundamental rights protection. ${ }^{3}$ This is in line with more general suggestions over the previous years that constitutional courts in EU Member States should use EU law as a standard of review, welcoming instances in which constitutional courts did so. ${ }^{4}$

Is this jurisprudence really such a positive development for European integration as these voices seem to suggest? If one takes into account the motivation of the CC for establishing this jurisprudence and assesses the subtleties of the new approach as to when EU fundamental rights will actually play a role in practice and who has a say on that, the picture might seem less bright. In fact, this new approach is a reaction to the expanding fundamental rights jurisprudence of the Court of Justice of the EU (CJEU), through which the court saw itself increasingly marginalized as an institution. To re-establish its influence, the court expands its own jurisdiction by also using the EU Fundamental Rights Charter as a standard of review; and at the same time, it expands the impact of domestic fundamental rights as opposed to EU fundamental rights in this context. This raises the question whether this jurisprudence is an instance of resistance or even backlash against the CJEU or rather a constructive contribution to a polyphonic human rights protection system in Europe.

To address this question, I first present in detail the content of the new framework of the relationship between EU and domestic fundamental rights (part B). This will allow us to assess to what extent this jurisprudence fulfils the criteria that constitute an act of pushback against an international or supranational court in the form of resistance or backlash (part C). If it does fulfil these criteria, this jurisprudence of the $\mathrm{CC}$ will contribute to an increasingly critical environment that many international courts are facing. It will join the ranks of other instances of pushback against these courts, a pushback which has become the object of broad scholarly attention in the recent past. ${ }^{5}$

Before turning to this discussion, I give a brief overview of the facts and the substantive arguments made in the "twin decisions" issued on 6 November 2019. This provides the necessary background to the discussion of the applicable fundamental rights framework, on which this paper will focus. In substance, the decisions concern, in two very similar constellations, the recently created "right to be forgotten" regarding personal information available on the internet.

In the first case (Right to be forgotten I, 1 BvR 16/13), the complainant challenged in a constitutional complaint a judgment of the Federal Court of Justice (Bundesgerichtshof). The complainant

\footnotetext{
${ }^{3}$ Thomas Kleinlein, Neue starke Stimme in der europäischen Grundrechts-Polyphonie, VerfassungSBLOG, (Dec 1, 2019), https://verfassungsblog.de/neue-starkestimme-in-der-europaeischen-grundrechts-polyphonie/.

${ }^{4}$ Davide Paris, Constitutional Courts as European Union courts. The current and potential use of EU law as a yardstick for constitutional review, 24 MAASTRICHT JOURNAL OF EUROPEAN AND COMPARATIVE LAW 792-821 (2017); referring to a letter of the then-President of the CJEU to the President of the Austrian Constitutional Court as well as to a presentation by the then EU commissioner Viviane Reding, who both welcomed the Austrian CC's application of the EU Charter of Fundamental Rights in its decision of 14 March 2012, docket number U 466/11-18, U 1836/11-13: Theo Öhlinger, Vorlagepflicht bei Verstoß eines nationalen Gesetzes gegen Artikel 47 GRCh - Anmerkungen, 25 EUROPÄISCHE ZEITSCHRIFT FÜR WIRTSCHAFTSRECHT 955 (2014).

${ }^{5}$ E.g. Mikael Rask Madsen, Pola Cebulak \& Micha Wiebusch, Backlash against International Courts: Explaining the Forms and Patterns of Resistance to International Courts, 14 InTERNATIONAL JOURNAL OF LAW IN CONTEXT 197-220 (2018); Karen J. Alter, James T. Gathii \& Laurence R. Helfer, Backlash against International Courts in West, East and Southern Africa: Causes and Consequences, 27 Eur. J. INT'L LAw 293-328 (2016); Ximena Soley \& Silvia Steininger, Parting Ways or Lashing Back? Withdrawals, Backlash and the Inter-American Court of Human Rights, 14 INTERNATIONAL JOURNAL OF LAW IN CONTEXT 237 (2018); Andreas Hofmann, Resistance against the Court of Justice of the European Union, 14 INTERNATIONAL JOURNAL OF LAW In ConteXt 258 (2018); Tom Gerald Daly \& Micha Wiebusch, The African Court on Human and Peoples' Rights: Mapping Resistance against a Young Court, 14 InTERnational Journal of LAW In ConteXt 294 (2018); Mikael Rask Madsen, The Challenging Authority of the European Court of Human Rights: from Cold War Legal Diplomacy to the Brighton Declaration and Backlash, 79 L. \& Cont. Probl. 141 (2016); Henry Lovat, International Criminal Tribunal Backlash, forthcoming in Oxford Handbook of International Criminal Law (Kevin John Heller et al. eds., 2020); Joseph Powderly, International Criminal Justice in an Age of Perpetual Crisis, 32 LEIDEN J. INT'L LAW 1 (2019); on investment arbitration: David Caron \& Esme Shirlow, Dissecting Backlash: The Unarticulated Causes of Backlash and Its Unintended Consequences, in The Judicialization of International Law: A MiXed Blessing? 159 (Andreas Follesdal \& Geir Ulfstein eds., 2018).
} 
sued German weekly journal "Der Spiegel”. In 1982 and 1983, the journal had published two articles about the complainant's criminal trial, in which he had been convicted of murder. These articles have been available in the online archive of the journal since 1999. A search for the complainant's name via an online search engine showed these articles among the top results. The complainant argued that given the time that has passed since the events, his general right of personality as enshrined in Articles 2 (1) and 1 (1) of the German Basic Law gives him the right to request that these articles should not appear as results of a simple name-based online search anymore. The CC agreed with this line of argument. Based on German constitutional law, the CC assessed the Federal Court of Justice's balancing of the personality right of the claimant and the freedom of opinion and the freedom of press of the journal. Even though the CC considered that there is still an interest of the public in having access to these journal articles via the online archive of the journal, the CC decided that the journal has to ensure through technical measures that these articles are not included in the top results of a simple name-based search by general online search engines.

In the second case (Right to be forgotten II, 1 BvR 276/17), the CC based its argumentation on EU fundamental rights as enshrined in the Charter. The case evolved around a TV broadcast that was uploaded to an online archive in 2010. In the broadcast entitled "Dismissal: the dirty practices of employers", the complainant is identified by name and accused of unfair treatment of an employee, who was dismissed by her company. A search for the complainant's name on Google displayed the link to this broadcast among the top results - a situation that the complainant sought to change. In contrast to the above case, the complainant did not take legal action against the broadcaster but against the search engine operator who refused to remove the broadcast from the search results. The CC emphasised that in this constellation, three sets of rights need to be balanced: the complainant's right to private and family life and to the protection of personal data pursuant to Article 7 and Article 8 of the Charter; Google's freedom to conduct a business pursuant to Article 16 of the Charter; and the freedom of expression of the broadcasting corporation pursuant to Article 11 of the Charter as a directly affected fundamental right of a third party. Based on the specific circumstances of the case, in particular the relatively short time that had passed since the broadcast was first published and the fact that the complainant had voluntarily contributed to it by agreeing to be interviewed, the CC concluded that the complainant's right does not have precedence over the other rights concerned.

Both cases are governed by EU legislation on data protection, currently the General Data Protection Regulation (GDPR). The cases differ with regard to the applicable EU law in one aspect: in the case Right to be forgotten I, the so-called media privilege applies. According to article 85 of the GDPR, Member States shall reconcile the right to the protection of personal data with the right to freedom of expression and information, including processing for journalistic purposes. The CC said that where this provision is applicable - as in the case Right to be forgotten I -, Member States are given a leeway in how to reconcile the rights mentioned in Article 85 GDPR. In contrast, where this provision does not apply - as in the case Right to be forgotten $I I-$, the Member States do not have any leeway, i.e. the subject matter is fully harmonized by EU law. This distinction is crucial because, as I will lay out in part B of this paper, the court creates different frameworks for the applicability of EU fundamental rights depending on whether the subject matter in the case is fully harmonized by EU law or not.

\section{B. A New Framework for the Relationship between Domestic and EU Fundamental Rights Protection in the German Legal Order}

In its twin judgements of November 2019, the CC establishes a two-prong framework for the relationship between domestic and EU fundamental rights protection. I will present both pillars of this jurisprudence below. 


\section{EU Fundamental Rights as Standard of Review}

The first major innovation of this jurisprudence relates to the standard used by the CC in the context of its constitutional review. For the first time, the CC uses the rights enshrined in the EU Fundamental Rights Charter as a standard for review. As of yet, the court had considered itself competent only to review whether domestic constitutional rights have been violated in a given case brought before it by way of a constitutional complaint. This corresponded to reading the constitutional provision conferring jurisdiction on the $\mathrm{CC}^{6}$ in a way that the term fundamental rights in this provision refers - only - to the fundamental rights section of the German Basic Law. So far, the court had repeatedly stated that "it is inadmissible to challenge the violation of European Community law. Rights under Community law are not among the fundamental rights, or rights that are equivalent to fundamental rights, the violation of which can be challenged under Article 93.1 no. 4a of the Basic Law..."?

The court now takes a different approach. In Right to be forgotten II, it argues that based on its "responsibility with regard to EU integration", the court shall ensure that EU fundamental rights are guaranteed. ${ }^{8}$ The notion of "responsibility with regard to EU integration" is an established concept of German constitutional jurisprudence that the CC deduced from Article 23 of the Basic Law, a norm that addresses matters of Germany's participation in the EU. While the CC has used this concept on multiple occasions to determine the competences and obligations of other constitutional organs such as the government or the legislator, in the present case, it applies this concept to determine the scope of its own competence. The court argues that, in light of this concept, German constitutional law has provided the court with the mandate to engage in a review of EU fundamental rights because these rights are a part of European integration. The claim thus is that German constitutional law requires the CC to ensure the protection of both domestic and EU fundamental rights.

By adopting this new approach, the CC joins a number of other constitutional courts in the EU that have recently started to apply the EU Fundamental Rights Charter as a standard of review. ${ }^{9}$ The Austrian Constitutional Court was the first court who chose that path and who provided a detailed explanation for taking that step. In its decision of Mar. 14, 2012, ${ }^{10}$ the court decided to henceforth review the cases brought before it both with regard to domestic fundamental rights and if applicable - to EU fundamental rights. ${ }^{11}$ Notably, the Austrian CC chooses a very different line of reasoning when compared to the German CC. It bases its jurisprudence on an argument drawn from EU law rather than from domestic constitutional law: the principle of equivalence. This principle requires that when Member States lay down the "procedural rules governing actions for safeguarding rights which individuals derive from Community law", the Member States have to ensure that these rules "are not less favourable than those governing similar domestic actions (the principle of equivalence) and do not render virtually impossible or excessively difficult

\footnotetext{
${ }^{6}$ Article 93 (1) of the Basic Law.

${ }^{7}$ BVerfG, March 28, 2006, docket number 1 BvR 1054/01, para. 77. This decision has been rendered by the Second Senate of the CC, while the decision Right to be forgotten II is a decision of the First Senate. To avoid the perception of a conflict between the two senates (which also would have had procedural implications), the First Senate has gone to great length arguing that both approaches are in fact compatible (paras 87-93). The First Senate said: "The treatment of corresponding constitutional complaints as inadmissible [by the Second Senate] was not based on an independent statement by this case law that fundamental Union rights were not applicable, but was merely a reflection of the inapplicability of the Basic Law" (para. 89). It remains to be seen how the Second Senate will respond to this argumentation.

${ }^{8}$ BVerfG, Nov. 6, 2019, Right to be forgotten II, docket number 1 BvR 276/17, para. 53, 67.

${ }^{9}$ Austrian Constitutional Court, Mar. 14, 2012, docket number U 466/11-18, U 1836/11-13; Conseil constitutionnel, Jul. 26, 2018, decision No. 2018-768DC; Corte Costituzionale, Jan. 23, 2019, docket number 20/2019. See also Conseil d'Etat [Belgium], Mar. 15, 2018, docket number 29/2018.

${ }^{10}$ Austrian Constitutional Court, Mar. 14, 2012, docket number U 466/11-18, U 1836/11-13.

${ }^{11}$ On the subsequent use of this jurisprudence, see Stefan Kieber \& Reinhard Klaushofer, The Austrian Constitutional Court Post Case-Law After the Landmark Decision on Charter of Fundamental Rights of the European Union, 23 (2) EUROPEAN PuBlic LAW 221 (2017).
} 
the exercise of rights conferred by Community law (the principle of effectiveness)". ${ }^{12}$ Thus, the rationale of the Austrian court is that because there is a review mechanism for domestic fundamental rights, review for EU fundamental rights should also be available. ${ }^{13}$ According to the Austrian court, that is at least true in situations in which the guaranty enshrined in the relevant Charter right corresponds to a right enshrined in the Austrian constitution. ${ }^{14}$ The German CC does not refer to this argument or any other argument drawn from EU law. Rather, it argues based on domestic law that there would be a "gap" in the fundamental rights protection if it did not engage in a review of EU fundamental rights as well. This argument will be discussed in more detail in part $\mathrm{C}$ of this paper. At its crux, the argument of the German CC is more comparable to the approach taken by the Italian CC. ${ }^{15}$ The Italian court has recently established a doctrine of "dual preliminarity" requiring domestic general courts to refer a preliminary question to the Italian $\mathrm{CC}$ when domestic and EU fundamental rights are at stake in a case. This doctrine was presented as a necessity in order to guarantee an effective fundamental rights protection and the centralized model of fundamental rights review that exists in Italy.

In contrast to other constitutional courts that have started to conduct a review regarding EU fundamental rights, the German CC takes a more restrictive approach, establishing a rather complex system of applicable review standards. The CC does not simply accept EU fundamental rights as a standard of review in situations in which EU fundamental rights are applicable according to EU law. Instead, the court reduces the scope of its new review standard to the minimum necessary for achieving its goals. In order to do so, the CC establishes a distinction between subject matters that are fully harmonized by EU law and subject matters in which Member States have a leeway. The constitutional courts in other Member States have not referred to this distinction in that way.

Concerning fully harmonized subject matters, EU fundamental rights are, according to the CC's new jurisprudence, exclusively applicable. Domestic fundamental rights have in general no role to play here - save for the existing jurisprudence on ultra vires and constitutional identity (see below). ${ }^{16}$ The exclusiveness approach for fully harmonized subject matters continues the established line of jurisprudence, i.e. that "sovereign acts of the European Union and acts of German public authority that are determined by Union law shall in principle not be measured against the standards of the Basic Law." ${ }^{17}$ The new approach - reviewing certain acts of German public authority that are determined by Union law with regard to their compatibility with the Charter rights - thus enables the CC to exercise jurisdiction in a field where at least in principle, it has not adjudicated since the Solange II decision of $1986 .{ }^{18}$ However, in contrast to the pre-Solange II era, the CC will now use EU fundamental rights rather than domestic fundamental rights as standard of review.

For subject matters beyond full harmonisation, the novel framework created by the CC is more multilayered. As I will outline in the next section, EU fundamental rights can potentially be a

\footnotetext{
${ }^{12}$ CJEU, Case C-326/96, Levez v. Jennings Ltd, E.C.R. 1998 I-7835, para. 18.

${ }^{13}$ The CJEU has given its appreciation of this argument in its decision of Sep. 11, 2014, Case C-112/13, Av B and others. The CJEU stressed that, in the context of the concrete review of legislation, a system in which general courts refer to the CC by way of interlocutory proceedings is only permissible under EU law when several strict conditions are fulfilled. The argumentation is based on the principle of primacy of EU law and the relevant Simmenthal jurisprudence of the court. However, in the context of constitutional complains such as in the present decisions of the CC, this restriction does not apply. See on the EU law limits on the application of EU law as yardstick for CCs in the different contexts, Paris, supra note 4, 811-814.

${ }^{14}$ Austrian Constitutional Court, Mar. 14, 2012, docket number U 466/11-18, U 1836/11-13, para. 35.

${ }^{15}$ Italian Constitutional Court, Jan. 23, 2019, docket number 20/2019, based on the argumentation in the decision Nov. 6, 2017, docket number 269/2017. On this new approach by the Italian CC, see Daniele Gallo, Challenging EU Constitutional Law: The Italian Constitutional Court's New Stance on Direct Effect and the Preliminary Reference Procedure, 25 EUR. J. INT'L LAW 434 (2019).

${ }^{16}$ E.g. BVerfG, Jun. 21, 2016, OMT, docket number 2 BvR 2728/13; Dec. 15, 2015, Solange III/European Arrest Warrant II, docket number 2 BvR 2735/14.

${ }^{17}$ E.g. BVerfG, Jun. 21, 2016, OMT, docket number 2 BvR 2728/13, para. 115.

${ }^{18}$ BVerfG, Oct. 22, 1986, Solange II, docket number 2 BvR 197/83, para. 132.
} 
standard of review in these cases - but their role is very limited. The CC gives as much space as possible to domestic fundamental rights.

\section{II. "Parallel" Applicability of EU and Domestic Fundamental Rights}

The second novelty of the twin decisions is that the CC abandons its concept of an exclusive relationship between EU and domestic fundamental rights. While, thus far the CC considered that either EU or domestic fundamental rights are applicable to a case at hand, ${ }^{19}$ it has now turned to recognizing a parallel applicability of both sets of fundamental rights. However, this parallel applicability only relates to subject matters that are not fully harmonized by EU law. As highlighted above, the CC exclusively uses EU fundamental rights as a standard of review in situations of full harmonisation. In this regard, the exclusiveness approach of the CC is still alive. Only beyond full harmonisation, the $\mathrm{CC}$ has changed its opinion on this issue. Both EU and domestic fundamental rights are now considered (at least prima facie) as standard of review by the CC.

As far as the CC has turned to parallel applicability, the approach corresponds - at its basis - to the approach taken by the CJEU on the matter. In Akerberg Fransson, the CJEU has accepted that in "situation where action of the Member States is not entirely determined by European Union law", EU and domestic fundamental rights standards can be applied at the same time. ${ }^{20}$ The CC however does not simply adopt the jurisprudence of the CJEU on the matter. It creates its own framework on how the newly recognized "parallel applicability" should translate into practice.

The particularity of this approach is that, despite its label, the new "parallel applicability" framework for situations beyond full harmonisation does not amount to the CC using in an equal and/or simultaneous manner EU and domestic fundamental rights as standard of review. Rather, in Right to be forgotten I, the CC establishes domestic law as the primary standard of review: in general, the court will use domestic fundamental rights as standard of review - and only exceptionally, it will use EU fundamental rights.

This concept follows from a two-step argumentation. The starting point of this argumentation is a novel presumption that the CC presents for the first time. This presumption has two elements. The first element serves as a justification for parallel applicability beyond full harmonisation. According to the court, whenever EU law leaves a leeway to the Member States for implementing the EU law provisions in question, it can be presumed that this leeway for implementation includes a leeway with regard to fundamental rights protection. ${ }^{21}$ That means that beyond full harmonisation, it is for the Member States to decide how and to what extent they protect fundamental rights. In this argumentation, the limits to parallel applicability as called for by the CJEU, i.e. primacy, unity and effectiveness of European Union law, ${ }^{22}$ do not play a role. For the CC, wherever there is no full harmonisation, there is in principle room for domestic fundamental rights standards. Moreover, the concept of a leeway does not only make it possible to support a parallel applicability of both standards but also to argue for domestic standards being the natural first point of reference. This element of the presumption thus relates to the distribution of competence between the EU and the Member States. The CC uses a subsidiarity rationale, claiming that where EU law does not harmonize a subject matter, there is no need for a compulsory EU regulation of fundamental rights and therefore there is no common EU fundamental rights standard.

The second element of the presumption which, from a conceptual perspective, is more remarkable than the first element relates to the substantive level of fundamental rights protection. The CC

\footnotetext{
${ }^{19}$ This approach has been prominent in the decision BVerfG, April 24, 2013, Antiterrorism Legislation, docket number 1 BvR 1215/07 (see the discussion of this decision in part C of this paper).

${ }^{20}$ CJEU, Case C-617/10, Åkerberg Fransson, ECLI:EU:C:2013:105, para. 29.

${ }^{21}$ BVerfG, Nov. 6, 2019, Right to be forgotten I, docket number 1 BvR 16/13, para. 50.

${ }^{22}$ CJEU, Case C-617/10, Akerberg Fransson, ECLI:EU:C:2013:105, para. 29.
} 
claims that it can be presumed that domestic fundamental rights guarantee a level of protection equivalent to that required by the EU Charter of Fundamental Rights. ${ }^{23}$ The argument is that even if domestic fundamental rights are used as the standard of review, their application also ensures in substance - the Charter rights. Therefore, the CC argues, domestic fundamental rights can be used as a primary standard of review. Their application does not undermine the level of protection required by the Charter. Remarkably, this reasoning inverses the reasoning on which the presumption in the Solange II decision of the CC is constructed. In Solange II, the CC argued that it can be presumed that the application of EU fundamental rights guarantees a level of protection that is equivalent to the level of protection required by domestic fundamental rights. ${ }^{24}$ This presumption served as a justification for the CC to step back and not to engage in the review of EU acts and domestic acts that are fully determined by EU law. In contrast, the new presumption which however does not replace the old presumption but coexists with it - serves the opposite purpose. The CC aims to step forward and to apply domestic fundamental right in cases in which, according to EU law, EU fundamental rights might (also) be applicable. Compared to the Solange II presumption, the new presumption, being a claim made by a domestic court, is rather bold. While in Solange II, the CC decided on the extent of the required domestic fundamental rights protection and claimed that EU law provides in substance an equivalent protection, the $\mathrm{CC}$ now decided on the extent of the required EU fundamental rights protection and claimed that domestic law provides in substance an equivalent protection. While it is comparatively natural for a domestic CC to decide on alternative ways in which domestic standards can be ensured, it is much less natural for a domestic court to decide on how EU law standards can be ensured. As this would be a question on which the CJEU might want to adjudicate, it will be interesting to see whether and how the CJEU will react to that jurisprudence of the CC.

The presumption for domestic fundamental rights as the primary standard of review is rebuttable. If it is rebutted, the CC will use EU fundamental rights as standard of review even in situations beyond full harmonisation. ${ }^{25}$ However, the court sets the bar for rebutting the presumption very high. Only "in exceptional circumstances", the CC will in fact apply EU fundamental rights. $^{26}$ Two scenarios are possible for such a rebuttal: when there are "specific and sufficient indications" that (1) the ordinary EU legislation in the case contains stricter fundamental rights requirements than allowing Member States to apply their domestic fundamental rights standards; or (2) the specific level of protection required by the Charter exceptionally does not correspond to domestic constitutional law. In order to establish the first scenario, the CC requires that the provisions of ordinary EU legislation determine a specific fundamental rights standard, explicitly expressing the wish of the EU legislator that this specific standard is applied by Member States as a harmonized standard. Notably, the court clarifies that it does not consider it to be a sufficient indication when the EU legislator merely refers to certain provisions of the Charter in the recitals to a legal act. ${ }^{27}$ This clarification shows that the CC is likely to be rather reluctant in recognizing that the presumption for domestic law as a primary standard of review is rebutted. A similarly high bar seems to apply to the second scenario. Here, the CC considers a rebuttal of the presumption that domestic fundamental rights standards correspond to those required by the Charter when it is evident from the jurisprudence of the CJEU that the CJEU considers certain Charter provisions to require specific standards that are not guaranteed by domestic fundamental rights law. For the CC, this is the case when the Charter contains guarantees that are not part of the domestic fundamental rights law. ${ }^{28}$

\footnotetext{
${ }^{23}$ BVerfG, Nov. 6, 2019, Right to be forgotten I, docket number 1 BvR 16/13, para. 55 .

${ }^{24}$ BVerfG, Oct. 22, 1986, Solange II, docket number 2 BvR 197/83, para. 107.

${ }^{25}$ BVerfG, Nov. 6, 2019, Right to be forgotten I, docket number 1 BvR 16/13, para. 63, 72.

${ }^{26} I d$. at paras. $63,65,67,68,72$ (orig.: "ausnahmsweise").

${ }^{27} I d$. at para. 68.

${ }^{28} I d$. at para. 69.
} 
This overview shows that in situations beyond full harmonisation, the parallel applicability of $\mathrm{EU}$ and domestic fundamental rights amounts to a superior position for domestic fundamental rights in this area. They are the primary standard of review based on a presumption that can only be rebutted in very limited circumstances. In practice, the parallel applicability is thus likely to remain largely rhetorical. This observation is one of the aspects that lead to inquire whether the new approach of the CC really contributes to a constructive judicial dialogue between the $\mathrm{CJEU}$ and the CC in fundamental rights matters or whether it is an example of judicial resistance against international and supranational courts, an issue discussed in the following section.

\section{Constructive Judicial Dialogue or Pushback against the CJEU?}

The relationship between the CJEU and the CC has never been free of friction. In some instances, the CC took a more critical stance towards the CJEU and EU law in general, in others, its jurisprudence was more "European law friendly". As this new approach structurally changes the parameters of the relationship between $\mathrm{EU}$ and domestic fundamental rights law in the German legal order as well as the relationship between the two courts, it is important to assess which legal-political tendency this change reflects: constructive dialogue or rather pushback against the CJEU. Determining this tendency also contributes to situating this jurisprudence in the broader debate about what seems to be increasing backlash and resistance against international courts. Given that the CJEU so far has encountered very few instances of open resistance by domestic courts, ${ }^{29}$ qualifying the nature of this judgement of the CC is particularly interesting.

In order to assess whether this jurisprudence of the CC should be read as instance of resistance or even as backlash against the CJEU, it is crucial to clarify these notions. In the discussion about the pushback against international courts, authors have suggested diverging concepts of backlash and resistance. Generally, backlash is considered to be the strongest form of pushback against courts. It is characterized by various factors. First, backlash is a "reaction to a development with the goal of reversing that development" ${ }^{30}$ The actor that is lashing back aims to reinstate a status quo ante that has been modified by a development that is perceived by this actor as unfavourable. The thrust is thus a resetting response: the actor responds to a specific development rather than merely changing its approach towards an unmodified situation; and the actor aims at restoring a previous state of affairs. Second, backlash "targets the institutions as such and their authority" 31 rather than contesting a certain legal norm or its interpretation by a court. ${ }^{32}$ The backlashing actor aims "to reduce the authority, competence, or jurisdiction of the court". ${ }^{33}$ The pushback is thus of a structural nature; it attacks the court as an institution rather than challenging its jurisprudence with regard to a certain subject matter. Third, for pushback in its extreme form, the actor ultimately rejects the institution as a whole. ${ }^{34}$ This is for example the case when a State withdraws from the jurisdiction of a court or when domestic actors including domestic courts cease to procedurally engage with a court and to implement its judgements. As some authors suggest, one can differentiate "backlash" as the extreme form of pushback from "resistance" as a lesser form of pushback. ${ }^{35}$ Although fulfilling the first and the second criterion of backlash, resistance thus understood does not reject the institution as such. Instead, an actor that resists against an

\footnotetext{
${ }^{29}$ Hofmann, supra note 5 .

${ }^{30}$ Madsen, Cebulak \& Wiebusch, supra note 5, at 200. See also Lovat, supra note 5.

${ }^{31}$ Madsen, Cebulak \& Wiebusch, supra note 5, at 203.

${ }^{32}$ For a definition of backlash that relates to the "methods rather than the aims of the actors, see Lovat, supra note 5.

${ }^{33}$ Wayne Sandholtz, Yining Bei \& Kayla Caldwell, Backlash and International Human Rights Courts, in CONTRACTING Human Rights 159-173, 160 (Alison Brysk \& Michael Stohl eds., 2018).

${ }^{34}$ More generally, backlash in various contexts is characterized by "actions taken in opposition to the system itself", Caron and Shirlow, supra note 5, at 160 .

${ }^{35}$ Soley \& Steininger, supra note 5, at 241 using a different terminology than Madsen, Cebulak \& Wiebusch, supra note 5.
} 
international court without lashing back "is still invested in the institution and seeks to reform it from within". 36

In the remainder of this section, I will use these three criteria for backlash and resistance in order to assess whether the recent jurisprudence of the German CC characterises as either of these forms of pushback.

\section{A Resetting Response of the CC}

The first criterion - a "reaction to a development with the goal of reversing that development" allows for a relatively clear evaluation in the current setting. The CC does react to a development: the jurisprudence of the CJEU on the applicability of the EU Fundamental Rights Charter and its relationship to the domestic fundamental rights protection - in combination with an increasing density of EU law in many subject matters. Since the much-discussed decisions Melloni ${ }^{37}$ and Akerberg Fransson ${ }^{38}$ from 2013, the CJEU has taken a broad approach to the applicability of the Charter, limiting at the same time the applicability of domestic fundamental rights. With regard to the scope of the Charter rights, it interpreted Article 51 of the Charter in a manner that went beyond the wording of this provision. While Article 51 stipulates that the Charter is addressed to "the Member States only when they are implementing Union law", the CJEU took the applicability to be broader, i.e. "where national legislation falls within the scope of European Union law". ${ }^{39}$ According to this jurisprudence, "the applicability of European Union law entails the applicability of the fundamental rights guaranteed by the Charter" ${ }^{40}$

This jurisprudence had consequences on two levels. By broadening the applicability of the Charter, the CJEU has expanded its authority in fundamental rights matters within the EU. As the institution competent for interpreting the Charter, the court obtained a say in a larger number of legal situations than before. This development towards a broadened authority is multiplied by the increase in the body of EU law. From the perspective of the CJEU, its say on fundamental rights questions is exclusive concerning fully harmonized subject matter. The applicability of domestic fundamental rights is excluded. ${ }^{41}$ In contrast, the CJEU - at least in principle - shares its jurisdiction regarding fundamental rights in situations where the "action of the Member States is not entirely determined by European Union law" ${ }^{42}$ The court accepted in Akerberg Fransson a limited parallel applicability of EU and domestic fundamental rights. This parallel applicability is however subject to the condition that it is "provided that the level of protection provided for by the Charter, as interpreted by the Court, and the primacy, unity and effectiveness of European Union law are not thereby compromised". ${ }^{43}$ As a result, the room for the applicability of domestic fundamental rights and thus for the domestic constitutional courts to exercise their jurisdiction is restricted.

This jurisprudence has triggered critique by many judicial and non-judicial actors in the EU. The German CC was one of the fiercest critics of this jurisprudence. It has explicitly voiced its opposition to this understanding of Article 51 of the Charter in its decision on the antiterrorism legislation from April 2013. ${ }^{44}$ The court threatened to consider the Akerberg Fransson decision as ultra vires act of the CJEU if it was to be understood as meaning that "absolutely any connection of

\footnotetext{
${ }^{36} I d$. Different understandings of the term resistance is adopted by other authors, e.g. Sandholtz, Bei \& Caldwell, supra note 33, at 160; Madsen, Cebulak \& Wiebusch, supra note 5.

${ }^{37}$ CJEU, Case C-399/11, Melloni, ECLI:EU:C:2013:107.

${ }^{38}$ CJEU, Case C-617/10, Åkerberg Fransson, ECLI:EU:C:2013:105.

${ }^{39} \mathrm{Id}$. at para. 29.

${ }^{40} \mathrm{Id}$. at para. 21.

${ }^{41}$ CJEU, Case C-399/11, Melloni, ECLI:EU:C:2013:107.

${ }^{42}$ CJEU, Case C-617/10, Åkerberg Fransson, ECLI:EU:C:2013:105, at para. 29.

${ }^{43} \mathrm{Id}$.

${ }^{44}$ BVerfG, 24 Apr. 24, 2013, Antiterrorism Legislation, docket number 1 BvR 1215/07.
} 
a provision's subject-matter to the merely abstract scope of Union law, or merely incidental effects on Union law, would be sufficient for binding the Member States by the Union's fundamental rights set forth in the EUCFR" ${ }^{45}$ This threat expressed the CC's concern that domestic fundamental rights as the court's own field of influence would lose practical importance. These concerns were primarily based on the CC's exclusiveness approach with regard to fundamental rights protection in the EU. The court considered - until it took, as outlined above, a different turn in November 2019 - that it can be either domestic or EU fundamental rights that are applicable to a given case - but not both. In an exclusiveness framework, a broader applicability of EU law automatically reduces the scope for applying domestic fundamental rights; and that would reduce the impact of the $\mathrm{CC}$ as an institution. The concern of the $\mathrm{CC}$ that such a development would take place could not be overcome by the subsequent jurisprudence of the CJEU. Although the CJEU took the critique by the German CC and by other actors into account and did not push the Åkerberg Fransson approach to its limit, a relative broad applicability of EU fundamental rights remains reality. ${ }^{46}$ This is due both to the jurisprudence of the CJEU on the applicability of the Charter and on the general increase of subject matters that are regulated by EU law.

The second consequence of the broad applicability of EU fundamental rights relates to the relationship between constitutional courts and general courts on the domestic level. A broad scope of the Charter leads to an empowerment of general courts in fundamental rights matters. This affects the judicial structure in legal orders such as the German one which is characterized by a centralized - rather than a diffuse - model of fundamental rights protection. The empowerment of general courts in fundamental rights matters is facilitated by the principles of direct effect and primacy of EU law which since their creation have strengthened domestic courts also beyond fundamental rights matters. ${ }^{47}$ Domestic courts have the power and the duty to assess whether acts of domestic authorities are in conformity with EU law, including EU fundamental rights law, and to set aside these acts if they do not comply with EU law. Based on these principles, the general domestic courts become fundamental rights reviewing actors in their own right; they become "miniature constitutional courts". ${ }^{48}$ This has caused the CC to lose its monopoly for fundamental rights review in the domestic legal order. In addition to this "disempowerment", ${ }^{49}$ ordinary courts have gained influence on the fundamental rights jurisprudence of the CJEU. The preliminary reference procedure gives them a tool to influence how and to what extent the CJEU shapes fundamental rights protection in the EU. ${ }^{50}$ The CC who so far did not use the Charter rights as standard of review could not influence the CJEU's fundamental rights jurisprudence in the same

\footnotetext{
${ }^{45} \mathrm{Id}$. at para. 91.

${ }^{46}$ For the more restrictive formulation in the subsequent jurisprudence see e.g. Case C-206/13, Siragusa, EU: C:2014:126, paras. 24-25:
}

"[Article 51 of the Charter] requires a certain degree of connection above and beyond the matters covered being closely related or one of those matters having an indirect impact on the other (...). In order to determine whether national legislation involves the implementation of EU law for the purposes of Article 51 of the Charter, some of the points to be determined are whether that legislation is intended to implement a provision of EU law; the nature of that legislation and whether it pursues objectives other than those covered by EU law, even if it is capable of indirectly affecting EU law; and also whether there are specific rules of EU law on the matter or capable of affecting it (...)."

\footnotetext{
${ }^{47} \mathrm{On}$ this impact of primacy and direct effect on the relationship between constitutional courts and general domestic courts, see e.g. Darinka Piqani, The Simmenthal Revolution Revisited: What Role for Constitutional Courts?, in NATIONAL COURTS ANd EU Law. New Issues, Theories And Methods 26-48 (Bruno de Witte et al. eds., 2016); Michal Bobek, The Impact of the European Mandate of Ordinary Courts on the Position of Constitutional Courts, in CONSTITUTIONAL CONVERSATIONS IN Europe. ACtors; Topics And Procedures 287-308 (Monica Claes et al. eds., 2012).

${ }^{48}$ Bobek, supra note 47.

${ }^{49}$ Piqani, supra note 47.

${ }^{50}$ On the general empowerment of domestic courts, inter alia by the preliminary reference procedure, see e.g. Karen Alter, The European Court's Political Power, 19 West European Politics 458 (1996).
} 
manner. In other words, where the applicability of the Charter is broad, the general domestic courts obtain a stronger voice in fundamental rights matters to the detriment of the CC.

Unlike the Austrian CC, the German CC seems to have been affected most notably by the broadened authority of the CJEU and the resulting perceived encroachment on the CC's competence. In Austria, it was a struggle for authority between the Austrian CC and the general domestic courts that led the Austrian CC to apply EU fundamental rights. ${ }^{51}$ In Germany, there was no such prominent struggle between domestic courts. Instead, the CC has aimed its attempt to re-establish its authority directly at the CJEU.

This struggle for authority with the CJEU was prominent at several occasions since the Akerberg Fransson decision of the CJEU. Most prominently, the CC had tried to maintain a say in fundamental rights cases within the scope of EU law by broadening its concept of constitutional identity review. Based on this notion and the idea of certain constitutional principles that are beyond the reach of European integration, the court constructed a way to conduct a limited review of fundamental rights. ${ }^{52}$ This review has become possible by partially expanding the protection of human dignity as required by the German Basic Law to other rights. However, conducting this kind of review comes with considerable challenges. Conceptually, it claims the primacy of certain constitutional law provisions over EU law and has thus the inherent potential of conflicts with the CJEU. It also provides a target for critique from the perspective of domestic constitutional law, in particular for eroding the notion of human dignity as conceived of by the German Basic Law. ${ }^{53}$ From the beginning, this review mechanism therefore did not seem able to fil the jurisdictional gap that the CC feared to result from a broad applicability of EU fundamental rights.

It is clear from the decisions Right to be forgotten I and Right to be forgotten II that the CC was motivated by the above developments when establishing its new jurisprudence on the Charter as review standard. In Right to be forgotten II, the CC addresses its reduced importance that results from an increasing density of EU law in many subject matters and thus from a broadening applicability of EU fundamental rights rather than domestic fundamental rights. ${ }^{54}$ It argues that without using the Charter as review standard, the court would be less and less able to exercise its judicial function with regard to fundamental rights protection. ${ }^{55}$ Although claiming to give reasons for why this new jurisprudence is necessary to guarantee fundamental rights protection for the individuals concerned, the court uses institutional arguments rather than arguments referring to the level of substantive protection. This shows the extent to which the court is mainly motivated by its importance as an institution and the attempt to regain more influence.

The institutional nature of the argumentation is especially vivid when the court addresses the alleged "gap" in the fundamental rights protection that would ensue if it did not use EU fundamental rights as standard of review. ${ }^{56}$ The court does not show - or even attempt to show - that the substantive level of human rights protection would be lower for the individuals concerned. Instead, the court seeks to show that the existing procedural mechanisms provided by general courts do not correspond to the procedural mechanism that is the centralized review by the CC. In doing so, it assumes that effective fundamental rights protection necessarily requires a centralized system as in the German legal order where a constitutional court holds the monopoly for setting aside legal acts which are not in conformity with fundamental rights law. The court does not provide arguments to support this assumption. Notably, it does not compare the centralized system to other possible systems for fundamental rights protection. In the EU, the fact that

\footnotetext{
${ }^{51}$ See the reaction of the Austrian Supreme Court, decision of Dec. 17, 2012, 9 Ob 15/12i.

${ }^{52}$ BVerfG, Dec. 15, 2015, Solange III/European Arrest Warrant, docket number 2 BvR 2735/14.

${ }^{53} \mathrm{On}$ the various points of critique that this jurisprudence triggers, see Dana Burchardt, Die Ausübung der Identitätskontrolle durch das Bundesverfassungsgericht, 76 ZAÖRV 527-551 (2016).

${ }^{54}$ BVerfG, Nov. 6, 2019, Right to be forgotten II, docket number 1 BvR 276/17, para. 60.

${ }^{55} \mathrm{Id}$.

${ }^{56} I d$. at paras. $60-66$.
} 
the centralized system is not the only option is evidenced by Member States who opted for a diffuse system of fundamental rights protection where general courts exercise such protection. ${ }^{57} \mathrm{EU}$ law follows a similar approach. Based on the CJEU's long standing jurisprudence on the primacy of EU law, all domestic courts are required to set aside domestic law that is in conflict with EU law. As established in Simmenthal, "every national court must, in a case within its jurisdiction, apply Community law in its entirety and protect rights which the latter confers on individuals and must accordingly set aside any provision of national law which may conflict with it". ${ }^{58}$ It is not a required part of this framework that a constitutional court oversees how general domestic courts apply EU fundamental rights. ${ }^{59}$ This goes to show that choosing a centralized system of fundamental rights review is not a legal requirement but rather a conceptual decision. ${ }^{60}$ The CC transposes this choice that the German Basic Law has made for domestic fundamental rights to the context of EU fundamental rights protection - without giving any solid legal arguments. Rather than a legal requirement, applying this model to the EU law context is a deliberate strategic move that benefits the CC as an institution - and that is indeed aimed at doing so.

The new approach taken by the CC responds to both aspects in which the jurisprudence of the CJEU has challenged the influence of the CC: the relationship to the general domestic courts and the relationship to the CJEU. Regarding the first aspect, the CC has taken back some of the control that it had lost to the general domestic courts. The CC regains full oversight over how general domestic courts apply fundamental rights law. In matters in which EU fundamental rights are applicable, the CC can annul judgments of the general courts that do not comply with the Charter (as interpreted by the CC). This re-establishes the relationship that existed between general courts and the $\mathrm{CC}$ before EU fundamental rights even came into being. It goes considerably beyond the limited review that had existed until Right to be forgotten II. Before this decision, the CC had restrained itself to reviewing whether general domestic courts of last instance have fulfilled their obligation to address the CJEU in a preliminary reference procedure. This review which was based on domestic constitutional law (the right to one's lawful judge as enshrined in Article 101 of the Basic Law) had led to different approaches taken by a chamber of the first senate and the second senate of the CC as to how strict the review exercised by the CC should be. This issue will now have less relevance as a full review has been re-established. Further, the new jurisprudence is likely to change the situation with regard to preliminary references. Although the CC has left it open in its decisions on the Right to be forgotten, the obligation of last instance courts under Article 267 TFEU to ask a preliminary question to the CJEU is likely to shift from the general courts of last instance to the CC. It is possible that these courts will thus be less inclined to involve the CJEU on a voluntary basis - which would leave more room for the CC to frame the dialogue with the CJEU.

As to the relationship between the $\mathrm{CC}$ and the CJEU, the new jurisprudence aims to reinstate the status quo ante. This means recreating a power balance between the two courts that is at least as favourable to the CC as it was before the CJEU started to expand its authority in fundamental rights matters. Assessing how the court achieves this aim is the object of the following section.

\section{Reducing Authority of the CJEU}

The second criterion for categorizing the decisions on the Right to be forgotten as backlash or resistance against the CJEU is that these decisions represent an action that aims "to reduce the authority, competence, or jurisdiction" of the CJEU. When assessing this criterion, the result

\footnotetext{
${ }^{57}$ E.g. Finland: Chapter 10 Section 106 of the Constitution; Sweden: Instrument of Government Chapter 11, Article 14.

${ }^{58}$ CJEU, Case 106/77, Amministrazione delle Finanze dello Stato $v$ Simmenthal, [1978] ECR 629, para. 21.

${ }^{59}$ Such a requirement also does not follow from the principle of equivalence. See on this discussion, Paris, supra note $4,812$.

${ }^{60}$ Stressing the political nature of this issue, Marten Breuer, Wider das Recht auf Vergessen ... des Bundesverfassungsgerichts!, Verfassungsblog 2019/12/02, https://verfassungsblog.de/wider-das-rechtauf-vergessen-des-bundesverfassungsgerichts/.
} 
is more ambivalent than with regard to the first criterion. Although some elements of this new jurisprudence might have an EU law friendly effect, other elements limit, for the German legal order, the impact of the Charter as well as - directly and indirectly - the authority of the CJEU in fundamental rights matters.

To start with, it is uncertain whether this new jurisprudence will strengthen the Charter within the domestic legal order or whether it will marginalize it to some extent. In the latter case, the impact of the jurisprudence of the CJEU in fundamental rights matters and the institutional standing of the CJEU as fundamental rights court would be affected. The Charter is the main legal instrument on which the authority of the CJEU in fundamental rights matters is based. Effects on the Charter and on the authority of the CJEU can result directly from the legal requirements that the new jurisprudence imposes on domestic actors (see below) and indirectly from the broader incentives that the jurisprudence sets for these actors. With regard to the broader incentives, some early commentators of these CC decisions have argued that the new jurisprudence will have positive effects on the visibility and application of the Charter. ${ }^{61}$ According to this argumentation, it might be the case that the fact that the CC uses the Charter as a review standard will motivate legal practitioners to engage more with the content and interpretation of the Charter and they might bring forward more arguments based on the Charter than before. However, one can have doubts as to whether the incentive created by the $\mathrm{CC}$ will be as positive. As the new framework means limiting the applicability of the Charter as standard of review for the CC almost exclusively to fully harmonized subject matters, the CC takes an explicitly restrictive approach. By communicating this restrictive approach to other domestic actors, the CC might create an atmosphere of reluctance rather than of encouragement. It thus remains to be seen to which extent such a restrictive approach can in fact motivate legal practitioners to engage more with the Charter than before or whether it might, inversely, not even discourage them in certain situations.

To assess how the authority of the CJEU is affected by the new jurisprudence of the CC, it is useful to distinguish between situations of full harmonisation and situations beyond full harmonisation. For fully harmonized subject matters, one can argue that the effectiveness of the Charter and the impact of the CJEU has a reasonable chance of being enhanced in the German legal order. The CC will be an additional actor monitoring the respect of Charter rights, reviewing the decisions of general courts as to how they guarantee these rights. In case the CC closely follows the jurisprudence of the CJEU as to the interpretation of the Charter rights, the new approach of the $\mathrm{CC}$ would not negatively affect the authority of the CJEU. This however requires the CC to address more preliminary questions to the CJEU than it did so far - which it claims to intend to do. ${ }^{62}$ The alternative scenario is that the CC will interpret the Charter by itself without involving the CJEU. If this scenario becomes reality, the monopoly of the CJEU for the interpretation of EU law will be undermined. Future practice will thus show what the effect of the new approach of the CC for the authority of the CJEU in fully harmonized subject matters will be.

That being said, the CC does not completely cede the yardstick in fully harmonized situations to EU law and to the interpretation by the CJEU. In particular, it is important to note that the CC does not give up its jurisprudence on constitutional identity review. The concept of constitutional identity aims at disapplying EU law based on domestic constitutional law provisions. In order to have a say in situations that the CC considered to be entirely determined by EU law (such as in the context of the European Arrest Warrant), the CC has used in the past constitutional identity for establishing a limited form of fundamental rights review based on domestic law. ${ }^{63}$ This jurisprudence has been developed by the second senate of the CC, while the decisions on the Right to be forgotten have been issued by the first senate of the CC. Considering that the latter declares that its

\footnotetext{
${ }^{61}$ Kleinlein, supra note 3. See also the reaction of the president of the CJEU Koen Lenaerts as quoted here: https://twitter com/KlausHempel2/status/1200071216654159874.

${ }^{62}$ BVerfG, Nov. 6, 2019, Right to be forgotten II, docket number 1 BvR 276/17, para. 70.

${ }^{63}$ BVerfG, Dec. 15, 2015, Solange III/European Arrest Warrant II, docket number 2 BvR 2735/14.
} 
new approach has no effect on the existing jurisprudence on constitutional identity review, it is likely that this instrument will continue to be used by the CC in the future if deemed necessary. ${ }^{64}$ As a result, the CC has broadened its possibilities in fully harmonized situations: it can decide based on EU fundamental rights and, as before, it can set aside EU law based on the domestic law principle of constitutional identity. However, by applying EU fundamental rights to situations of full harmonisation in which the CC previously did not adjudicate, the CC might have less incentive to use its other mechanism such as constitutional identity review to construct a basis for its jurisdiction. From now on, the $\mathrm{CC}$ can have a say on such situations by simply using EU fundamental rights as a review standard. The motivation to continue broadening the constitutional identity review will thus be less strong. This might reduce the cases in which the CC challenges the CJEU with regard to specific norms of EU law, i.e. it might reduce the risk for normrelated contestation. ${ }^{65}$ Yet the potential cases in which the CC will challenge the CJEU based on constitutional identity might appear even more conflictual than before.

The prospects for the authority of the CJEU for not fully harmonized subject matters are rather unfavourable from the outset. Here, the novel framework of parallel applicability is of particular interest. In fact, the parallel applicability of domestic and EU fundamental rights as spelled out by the CC seems to be a double-edged sword. On the one hand, the CC might advocate that its approach represents more tolerance towards EU law as standard of review. This seems to be an improvement for the relationship between $\mathrm{EU}$ and domestic law and thus for the relationship between the CC and the CJEU - as it is less confrontational than the concept of exclusive applicability of either EU or domestic fundamental rights. However, the way in which the CC designs its version of parallel applicability has the potential of having the opposite effect. The issue lies with the court's "primary standard of review". As outlined above, the CC has created a presumption that - beyond full harmonisation - domestic law will in general serve as standard of review; only in exceptional cases the presumption can be rebutted to the effect that EU fundamental rights are used as standard of review. The role of EU fundamental rights in this context is thus very limited.

This presumption for domestic fundamental rights which the CC has created as guideline for its own review raises the question as to how it might affect the review exercised by general domestic courts. Although the presumption appears to be of a procedural nature, thus only influencing the review by the CC, the statements of the CC in Right to be forgotten I convey a different impression. They seem to imply that the "primary standard of review" translates into a substantive rank relationship between EU and domestic fundamental rights - with domestic fundamental rights applicability trumping EU fundamental rights in situations beyond full harmonisation. If these statements are meant to establish such a substantive rank relationship, general domestic courts in Germany would be henceforth required by the CC to give precedence to domestic fundamental rights in this context. Now, it is true that the CC states that its jurisprudence does not prevent general domestic courts from applying EU fundamental rights and, where necessary, addressing the CJEU in a preliminary reference procedure according to Article 267 TFEU. ${ }^{6}$ This statement appears to go against the establishment of a substantive rank relationship. Immediately after this statement however, the CC stresses that the general courts have to "also" apply the domestic fundamental rights (in situations without full harmonisation); and that in this context, the "abovementioned" principles regarding the "substantive relationship" ("materielles Verhältnis") between EU and domestic fundamental rights apply. ${ }^{67}$ The CC thus refers to its "primary standard of review" as "substantive relationship" between EU and domestic fundamental rights. Accordingly, the CC seems to consider the "primary standard of review" to mean "primary applicability" of

\footnotetext{
${ }^{64}$ BVerfG, Nov. 6, 2019, Right to be forgotten II, docket number 1 BvR 276/17, para. 49.

${ }^{65}$ On the notion of contestation as used here, see Soley \& Steininger, supra note 5, 240.

${ }^{66}$ BVerfG, Nov. 6, 2019, Right to be forgotten I, docket number 1 BvR 16/13, para. 73.

${ }^{67} I d$.
} 
domestic fundamental rights by all courts within the German legal order. Primary applicability would thus require general domestic courts to give precedence to domestic fundamental rights. Contrary to what the CC claims, the general courts would thus no longer be free to apply EU fundamental rights in the way they did before. This reduces the impact of EU fundamental rights on the German legal order.

Obliging the general domestic courts to primarily apply domestic fundamental rights has potentially a restricting effect on how often general courts will initiate preliminary reference procedures under Article 267 TFEU. When, beyond full harmonisation, domestic fundamental rights are applicable in principle and when the bar to rebut the presumption for this primary standard is very high, parties to legal disputes are likely to focus on their domestic constitutional law arguments rather than trying to rebut the presumption. Courts might thus receive less incentives by parties to initiate a preliminary reference procedure before the CJEU. Further, the demanding requirements to rebut the presumption would oblige courts to make a considerable additional effort in their argumentation if they want to apply EU fundamental rights according to the guidelines established by the CC. This requirement creates a new practical hurdle for applying EU fundamental rights as compared to what existed prior to the new jurisprudence of the CC.

The authority of the CJEU is affected in two ways by the new approach of the CC concerning the substantive relationship between EU and domestic fundamental rights in situations in which EU law does not provide a full harmonisation. First, if domestic courts apply EU fundamental rights to a lesser degree, this reduces the impact in Germany of the CJEU's fundamental rights jurisprudence. The less EU fundamental rights are applied, the less it matters for the German legal order what the CJEU has to say on these rights. The importance of the CJEU as a fundamental rights court diminishes for the German legal order. Second, the scope of authority exercised by the CJEU is affected when general domestic courts are de facto dissuaded from asking preliminary questions to the CJEU. It is important for the CJEU - as it is for other international courts - that a broad number of actors are able and willing to bring legal questions before the court. ${ }^{68}$ Less cases mean less possibility for the court to impact the legal order. For the CJEU in its capacity as a fundamental rights court, it is particularly relevant if general domestic courts are dissuaded from bringing cases to the court. There is no direct access of individuals to the CJEU in fundamental rights matters as is the case before the ECtHR. Consequently, the preliminary reference procedure and the ability and willingness of domestic courts to initiate this procedure is important as a substitute for direct access. If the jurisprudence of the CC dissuades the general courts from this procedure, it affects the authority of the CJEU - not only with regard to the German legal order but also conceptually with regard to the CJEU as fundamental rights court of the EU.

The authority of the CJEU is however not only affected in the context of subject matters that are not fully harmonized. There are two further aspects that concern the fundamental rights authority of the CJEU on a more general level. First, by establishing this new approach to the relationship between $\mathrm{EU}$ and domestic fundamental rights, the $\mathrm{CC}$ de facto rejects the jurisprudence of the CJEU on Article 51 of the Charter in its entirety. If henceforth both the CC and the general domestic courts in Germany decide about the applicability of EU fundamental rights according to the standards set out by the CC in the decisions of November 2019, this de facto leaves no room for Article 51 of the Charter and the jurisprudence of the CJEU on the matter. For the German legal order, the competence of the CJEU for determining the applicability of the Charter is undermined. The CC - who has been very critical with regard to how the CJEU interpreted Article 51 - has now decided not to fight about this interpretation any longer. Rather, it appears to opt for a more radical solution, substituting the Article 51 system by its own approach to the relationship between

\footnotetext{
${ }^{68} \mathrm{On}$ usage potential of international court as one of the various factors for the effectiveness of international courts, see Yuval Shany, Assessing the Effectiveness of InTERnational Courts 58 (2014). On a broad range of engaged actors as bases for the authority of international courts, see Karen Alter, Laurence Helfer \& Mikael Madsen, InTERnational COURT Authority Chapter 2 (2018).
} 
$\mathrm{EU}$ and domestic fundamental rights. In doing so, the $\mathrm{CC}$ takes back control over this relationship for the German legal order to the detriment of the authority of the CJEU.

The second general aspect in which the new jurisprudence of the CC affects the authority of the $\mathrm{CJEU}$ relates to the dialogue between the two courts. At first sight, the CC seems open to actively involve the CJEU concerning EU fundamental rights matters by preliminary reference procedure. The CC mentions that it wants to address the CJEU in relation to the interpretation of Charter provisions. However, when it comes to applying EU fundamental rights, determining the content of Charter rights is only the second step. The first step is to decide whether the Charter rights are applicable at all. With regard to the applicability of the Charter, the CC does not intend to involve the CJEU by way of preliminary reference. In particular, the CC does not plan to ask a preliminary question as to the issues that are crucial to the CC's new delimitation between EU and domestic fundamental rights: whether a specific provision of EU secondary law fully harmonizes a subject matter or contains a leeway for Member States; and whether a provision of EU secondary law contains specific fundamental rights requirements that would be able to rebut the presumption for domestic fundamental rights as a primary standard of review. These are questions of EU law that, so it seems, the CC wants to decide on its own. From the perspective of the CC, this approach makes sense. Only by not involving the CJEU in the question of whether EU fundamental rights should be applied in a specific case, the CC can re-establish its authority on the relationship between EU and domestic fundamental rights and put into effect its motive to reinstate a situation in which the CJEU has less power.

Finally, the CC weakens the authority of the CJEU for determining the applicability of the Charter also in an a more indirect manner. According to the CC's approach, the EU actor competent for determining the applicability of the Charter is primarily the EU legislator rather than the CJEU. This claim results from the statement of the CC about how the presumption for domestic fundamental rights can be rebutted - concerning the first out of the two possibilities described in part B of this paper. A rebuttal requires that ordinary EU legislation explicitly establishes a certain fundamental rights standard that precludes Member States from taking their own approach. A mere reference to one of the Charter rights in the legislative act is not sufficient. Conceptually, the CC thus gives a considerable power to the EU legislator to decide whether Charter rights are applicable or not. However, such full discretion of the EU legislator is not in line with the idea that the Charter has a legal rank equivalent to primary EU law. Primary EU law should be binding on the EU legislator and its applicability should not be at the legislator's full discretion. Rather, it should be (inter alia) for the CJEU to ensure that the legislator respects these standards. Thus, when taking the formulation chosen by the EU legislator as point of reference for whether to apply the Charter rights or not, the CC undermines both the primary law rank of the Charter and the corresponding authority of the CJEU.

Despite some ambiguities as to the future effects that the jurisprudence of the $\mathrm{CC}$ will have in practice, the above assessment has highlighted that the $\mathrm{CC}$ at least to some extent aims at reducing the authority of the CJEU in fundamental rights matters. One can thus characterize this jurisprudence as pushback of a structural nature that addresses the CJEU as a fundamental rights court.

\section{Rejection or Acceptance of the CJEU as an Institution?}

The motivation of the CC to react to a development triggered by the CJEU and its aim to reduce the authority of the CJEU in fundamental rights matters do not necessarily mean that the CC rejects the CJEU as an institution altogether. Such a rejection would require additional indications, for example an unwillingness to engage in judicial dialogue with the CJEU or open noncompliance with its judgments. This is not the case here. At least formally, the CC emphasises that the CJEU has the monopoly of interpretation with regard to EU law and that the CC will refer to the CJEU in a preliminary reference procedure in cases in which the interpretation of the Charter provisions is unclear. In view of its reluctance so far to refer a question to the 
CJEU, the CC even stresses that its new jurisprudence will lead it to refer questions to the CJEU more often. The CC thus accepts the CJEU as an institution competent to rule in fundamental rights matters.

Moreover, based on its new approach, the CC seeks to actively influence the fundamental rights jurisprudence of the CJEU in substance. Already in the past, the CC was not shy to explicitly put forward its own interpretation of EU law provisions on different subject matters, with the aim to convince the CJEU of this interpretation. ${ }^{69}$ Increasing the number of preliminary references to the $\mathrm{CJEU}$ on fundamental rights issues will give more opportunities to the $\mathrm{CC}$ to suggest and promote its view as to how to interpret Charter provisions. Seeking to influence the CJEU is based on an inherent acceptance of the CJEU as an institution. This motivation corresponds to the abovementioned criterion for resistance as a category of pushback: a willingness to "reform" the institution from within. ${ }^{70}$ The CC takes this approach.

In sum, the new jurisprudence of the CC should be characterized as an instance of resistance. The CC resists against the CJEU in its function as a fundamental rights court, attempting to reduce the authority of the CJEU and reversing a development that it considered to be unfavourable to its own authority. This is structural pushback aimed the CJEU's function rather than at individual decisions or norms. However, the CC does not reject the CJEU as a fundamental rights institution altogether. It accepts, in principle, that the CJEU has such a role, although seeking to limit this role. Consequently, the third criterion of backlash, which would be the extreme form of pushback, is not fulfilled. The jurisprudence thus qualifies as resistance rather than backlash.

An additional aspect that contributes to categorizing the jurisprudence of the CC as resistance is the question how many open conflicts between the two courts there are likely to be in the future. It is true that it is uncertain to what extent the CJEU will accept the new approach of the CC to consider domestic law as a primary standard of review. This element of the new jurisprudence indeed bears the potential for a conflict. Yet at least at its surface, the language of parallel applicability of EU and domestic fundamental rights seems less confrontational than the previous exclusiveness approach of the CC; and less confrontational than the CC's constitutional identity review. Although the struggle for authority between the courts persists in substance, the "parallel applicability" framing might trigger a more harmonious perception. If, however, the CJEU rejects the CC's version of parallel applicability, the harmony might be short-lived.

\section{Conclusion}

The German CC is neither the first nor the only constitutional court in the EU to apply the Charter as standard of review. However, the new jurisprudence of the CC is remarkable in several respects. The CC has clearly expressed its motivation to counter a development that had reduced its importance as an institution. The court aims at rebalancing to its benefit the institutional relationship between the CJEU and itself. To achieve that aim, the CC establishes a complex system delimitating the applicability of domestic and EU fundamental rights. This system reduces the relevant authority of the CJEU as far as possible without openly defying the CJEU. In doing so, the new jurisprudence classifies as resistance against the increasing role of the CJEU in fundamental rights matters, however without constituting an instance of backlash. The CC measures its resistance to the extent necessary to regain authority without rejecting the CJEU as an institution.

\footnotetext{
${ }^{69}$ Eg. BVerfG, Jan. 14, 2014, docket number 2 BvR 2728/13, paras. 55-100; BVerfG, Jul. 18, 2017, docket number 2 BvR 859/ 15. On such "preemptive opinions" about the interpretation of EU law by domestic courts, see Stacy Nyikos, Strategic interaction among courts within the preliminary reference process - stage 1: national court preemptive opinions, 45 EUR. J. POL. RES. 527 (2016).

${ }^{70}$ Soley \& Steininger, supra note $5,241$.
} 
Compared to several other much discussed frictions between domestic courts and the CJEU, the CC's decisions on the Right to be forgotten are of a more structural nature. Many of these frictions mainly concerned the contestation of specific norms of EU law or their interpretation by the CJEU such as in the Ajos decision of the Danish Supreme Court ${ }^{71}$ or the Taricco Saga between the Italian Constitutional Court and the CJEU. ${ }^{72}$ The decisions of the CC go beyond that. They address the institutional role of the CJEU rather than its jurisprudence on isolated legal issues. As a result, their importance as instances of pushback are higher from a conceptual perspective, despite the less confrontational tone.

If one takes into account the role of the $\mathrm{CC}$ as a well-established, influential constitutional court in Europe, it is not surprising that the CC takes, yet again, a clear stance against the CJEU. Powerful actors are arguably more likely to push back against a court than less powerful actors. ${ }^{73}$ And this might be even more so when these powerful actors see their authority diminishing. As the CC has been a powerful actor both domestically with regard to other judicial and constitutional actors as well as within the European sphere in relation to the CJEU and the constitutional courts of other member states, this has made it more likely for the court eventually to resist on a structural basis. At the same time, the influential role of the CJEU increases the suspense for the future: it makes it particularly interesting to see how the CJEU and other courts in the EU will react to this development.

\footnotetext{
${ }^{71}$ Danish Supreme Court, Dec. 6, 2016, Case 15/2014.

${ }^{72}$ CJEU, C-42/17, Taricco II, ECLI:EU:C:2017:936; and CJEU, C-105/14, Taricco I, ECLI:EU:C:2015:555; Italian CC, order 24/2017 and decision 115/2018.

${ }^{73}$ Lovat, supra note 5.
}

Cite this article: Burchardt D (2020). Backlash against the Court of Justice of the EU? The Recent Jurisprudence of the German Constitutional Court on EU Fundamental Rights as a Standard of Review. German Law Journal 21, 1-18. https://doi.org/10.1017/glj.2020.16 